\begin{tabular}{|c|c|c|}
\hline \multirow{2}{*}{$\Gamma \mathrm{TT}$} & $\begin{array}{l}\text { International Journal of Current Research in } \\
\text { Biosciences and Plant Biology }\end{array}$ & 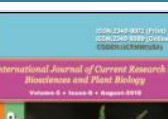 \\
\hline & Volume $5 \bullet$ Number 8 (August-2018)・ISSN: 2349-8080 (Online) & sines \\
\hline $\begin{array}{l}\text { EXCELLENT } \\
\text { PUBLISHERS }\end{array}$ & Journal homepage: www.ijcrbp.com & wnw.ictichpocom \\
\hline
\end{tabular}

\title{
Effect of Processed Cajanus cajan Seed on Some Serum Enzyme Levels in Albino Wistar Rats
}

\author{
R. U. Ukpanukpong1*, S. O. Bassey ${ }^{1}$, M. A. Adejoorin², C. I. Eko1, \\ W. A. Omang ${ }^{1}$ and E. D. Eyong ${ }^{1}$ \\ 1Department of Biochemistry, University of Calabar, Calabar-Nigeria \\ ${ }^{2}$ Department of Chemical Sciences, Biochemistry Unit, Joseph Ayo Babalola University, \\ Ikeji-Arakeji, Nigeria
}

*Corresponding author.

\begin{tabular}{|c|c|}
\hline Article In & ABSTRACT \\
\hline $\begin{array}{l}\text { Date of Publication: } \\
\text { 06 August } 2018\end{array}$ & \multirow{3}{*}{$\begin{array}{l}\text { The present study was undertaken to investigate the nutritional effect of processed Cajanus } \\
\text { cajan on serum enzyme activities, creatinine and bilirubin level in albino Wistar rats. Sixty four } \\
\text { (64) female albino Wistar rats were used in this and designated into } 8 \text { study groups. The study } \\
\text { groups comprised of Cajanus cajan fed rat groups designated as control group A; raw group B; } \\
\text { fermentation without decantation group C; boiled group D; roasted group E; fermentation } \\
\text { with decantation group F; soaked group G. Feeding was observed for } 28 \text { days during which } \\
\text { body weight indices of the Cajanus cajan fed albino Wistar rats were significantly increased } \\
\text { ( } P<0.05) \text { when compared to the control group. The phytochemical screening showed the } \\
\text { presence of alkaloids, phenolics, saponin, phytate, oxalate and flavonoids. Evaluation of } \\
\text { proximate nutrient composition which is an important nutritional index, to know the } \\
\text { constituents present in any food carbohydrate, protein, fat, fibre, ash content and moisture } \\
\text { content were among the proximate data obtained. Creatinine level, there was significant } \\
\text { decrease in creatinine activity in group A, B and F at } P<0.05 \text { compared to control. The } \\
\text { bilirubin level in group A and B showed significant decrease } P<0.05 \text { compared to control. } \\
\text { There was a significant decrease in AST and ALT in group A, B and F when compared to the } \\
\text { control at ( } P<0.05) \text {, while groups C, D, G showed no increase significant at ( } P<0.05) \text { compared } \\
\text { to control. At }(P<0.05) \text { the ALP level in group A and B (boiled and cooked) showed a } \\
\text { significant decrease at when compared to the control, while groups C, D, F showed an } \\
\text { increase which was not significant at }(P<0.05) \text { compared to control. The GGT activity in group } \\
\text { A and B (boiled and soaked) shows a significant decrease at }(P<0.05) \text { compared to the control, } \\
\text { while groups C, D, F and G (fermentation with decantation, fermentation without } \\
\text { decantation, roasted and soaked) showed an increase which was not significant at }(P<0.05) \\
\text { compared to control, but in group E (raw) there was a significant increase at }(P<0.05) \\
\text { compared to the control. The LDH activity in group A, B and F showed significant decrease } \\
\text { compared to the control at }(P<0.05) \text {. }\end{array}$} \\
\hline Keywords & \\
\hline $\begin{array}{l}\text { lyte level } \\
\text { hate nutrient } \\
\text { sition }\end{array}$ & \\
\hline
\end{tabular}




\section{Introduction}

Legumes belong to the family of Leguminosae and consist of oilseeds such as soybeans, peanuts alfalfa, clover, mesquite and pulses, including the dry grains of peas, chickpea, lentils, peas, beans and lupins. Production and use of legumes date back to ancient cultures in Asia, the Middle East, South America, and North Africa. They are cultivated throughout the world for their seeds, harvested and marketed as primary products. Grain legumes are grouped into pulses and oilseeds. The pulses are different from leguminous oilseeds, which are primarily utilized for oil (Scheider, 2002). There are about 1300 species of legumes, with only about 20 commonly consumed by humans (ReyesMoreno et al., 1993). Notable amongst legume species are chickpeas (Cicer arietnum), pigeon pea (Cajanus cajan), lentil (Lens culinaris), mung bean (Vigna radiata), soybean (Glycine max), winged bean (Psophocarpus tetragonoloba), cowpea (Vigna unguiculata), pea (Pisum sativum), groundnut (Arachis hypogaeaa), and black gram (Vigna mungo), to mention but a few. Some of the most important legumes in the world are peas, beans, peanuts, soybeans and chickpea (ReyesMoreno et al., 2000). Legumes have a special place in the diet of humans, because they contain nearly 2-3 times more protein than cereals (Reyes-Moreno et al., 1993). Cowpeas, for example, contain about $25 \%$ protein (Annor et al., 2010). Legumes are also excellent sources of complex carbohydrates and have been reported as beneficial for cardiovascular diseases and diabetes by some researchers (Jacobs and Gallagher, 2004), probably due to the large amounts of water-soluble fiber and a large content of phenolics (Enuijiugh, 2010).

Legume seeds are rich in lysine and poorer in sulphur-containing amino acids (methionine and cysteine) compared to cereals. Lysine is the first limiting amino acid so it is important that legumes complement cereals in lysine balance. Legume proteins are composed of several thousand specific proteins. About 70 to $80 \%$ of the crude protein in legume seeds is storage protein. The non-storage proteins are enzymes, enzyme inhibitors, hormones, transporting, structural and recognition proteins (Grant and Driesscher, 1993). The main protein fractions of legume seeds are albumin and globulin, which can be separated into two major fractions, vicilin and legumin. The relative proportion of legumin to vicilin varies with genotype, but vicilin is the major protein fraction in all legumes except Vicia faba. Vicilin contains low sulphur-containing amino acids; this is the main cause of the relatively poor amino acid composition of pea. The main globulin fractions differ in their amino acid composition, molecular weight of protein subunits and physico-chemical properties (Casey, 1998).

\section{Materials and methods}

\section{Experimental animals}

Sixty-four (64) female albino rats weighing between 250-262g were purchased from Ladoke Akintola University of Technology, Ogbomosho, Nigeria and used for the study. The rats were randomly assigned on the basis of their body weight into eight (8) study groups of four (8) rats each. Normal feeds and tap water were given to the rats, ad-libitum and food and water intake was noted. They were kept in secure wooden cages of eight (8) rats per cage placed in a well-ventilated animal room of Joseph Ayo Babalola University at normal temperature of $30-35^{\circ} \mathrm{C}$. The cages were cleaned daily and the rats were treated according to the international guidelines for the care and use of laboratory animals (NIH, 2008). The animals were allowed for two weeks of acclimatization and their weights were measured before treated commenced.

\section{Chemicals}

Chloroform and other chemicals of analytical grade were obtained from Fam-lab Nigeria Limited. Distilled water was also used during the experiment.

\section{Identification and authentication}

Cajanus cajan seeds were purchased from Oja Oba market, Ilesha, Osun State. The samples were taken 
for identification to the department of Botany, Obafemi Awolowo University (OAU).

\section{Source and preparation of Cajanus cajan seeds}

The Pigeon pea seeds were purchased from Oja Oba market, Ilesha, Osun State. The research project was carried out at the Biochemistry Research Laboratory, Department of Chemical Sciences (Biochemistry option), Joseph Ayo Babalola University, Ikeji-Arakeji, Osun State Nigeria, from March-May, 2017. 7kg of the Pigeon pea seeds were cleaned by sorting to remove extraneous materials and were weighed $1 \mathrm{~kg}$ each to make seven desired groups. Each was subjected to either of this process Raw, Cooked, Boiled, Soaked, Roasted, Fermentation with decantation or Fermentation without decantation.

\section{Experimental design}

The grouping and feeding of processed Cajanus cajan given to rats were designated into eight study groups; Group A: Designated as Boiled Cajanus cajan seed rats administered a portion of Boiled Cajanus cajan seed and water ad-libitum. Group B: Designated as Cooked Cajanus cajan seed rats administered a portion of Cooked Cajanus cajan seed and water ad-libitum. Group C: Designated as Fermentation with decantation Cajanus cajan seed rats administered a portion of Fermentation with decantation Cajanus cajan seed and water ad-libitum. Group D: Designated as Fermentation without decantation Cajanus cajan seed rats administered a portion of Fermentation without decantation Cajanus cajan seed and water ad-libitum. Group E: Designated as Raw Cajanus cajan seed rats administered a portion of Raw Cajanus cajan seed and water ad-libitum. Group F: Designated as Roasted Cajanus cajan seed rats administered a portion of Roasted Cajanus cajan seed and water ad-libitum. Group G: Designated as Soaked Cajanus cajan seed rats administered a portion of Soaked Cajanus cajan seed and water ad-libitum. Group H: Designated as control group rats administered a portion of normal rat feed and water ad-libitum for 28 days.

\section{Phytochemical analysis}

Quantitative analysis was carried on each of the test samples using diverse methods. The phytochemicals: flavonoids, tannins, saponins, phenolics, phytate and oxalate were tested for, using the method of of (Trease and Evan, 1996; Harbone, 1973; Sofowora, 1993).

\section{Sacrifice of the animals}

At the end of the experiment period, rats in each study group were fasted overnight and sacrificed under anaesthesia by cervical dislocation.

\section{Blood collection}

After the rats have been sacrificed, 3-4ml of blood was collected from each rats and placed in specific sterile bottles (EDTA bottles for serum enzymes analysis) for further analysis.

\section{Creatinine}

Method: Colorimetric method. Principle: Creatinine in alkaline solution reacts with picric acid to form a coloured complex. The amount of the complex formed is directly proportional to the creatinine concentration.

\section{Determination of serum albumin}

The method described by Wright and Plummer 1974 was used to determine the albumin concentration.

\section{Determination of l-aspartate aminotransferase} (ec. 2.6.1.2) activity

L-aspartate aminotransferase (AST) activity was estimated by the method of Reitman and Frankel 1957.

\section{Determination of l-alanine aminotransferase (ec. 2.6.1.2) activity}

L-alanine aminotransferase (ALT) activity was 
estimated by the method of Reitman and Frankel 1957.

\section{Determination of alkaline phosphatase activity}

Alkaline phosphatase activity was assayed according to the method described by Bassey et al. (1946) and modified by Wright and Plummer (1974).

\section{Statistical analysis}

Data obtained were analysed using Microsoft Office Excel 2007 and expressed as Mean \pm SEM. The statistical package SPSS version 16.0 was used to established statically significance at $(P<0.05)$.

\section{Results and discussion}

The results of the present study are given in Figs. 18. Legumes have been reported to have a special place in the diet of humans and animals, due to their nutritional. The concentrations of the phytochemical were determined by carrying out quantitative analysis and the phytochemical screening showed the presence of alkaloids, phenolics, saponin, phytate, oxalate and flavonoids (Fig. 1) which were in conformity with the results of Kataria (1995). Evaluation of proximate nutrient composition is an important nutritional index, to know the constituents present in any food; carbohydrate, protein, fat, fibre, ash content and moisture content were among the proximate data obtained. Results obtained from the proximate analysis of the different processed Cajanus cajan (Fig. 2) are in agreement with the research carried out by Solomon et al. (2017). Pigeon pea has high carbohydrate content and protein content which make it a good source of protein and carbohydrate. The ash content was within the range reported by Khalil and Monan (1990), and for the other nutrients analysed the results obtained were in accordance with Salunke et al. (1985). The mineral composition and vitamins also showed similar results (Fig. 3 and Fig. 4).

They body weight indices of the experimental animals, were also measured there was a significant increase in boiled, cooked, fermentation with decantation, fermentation without decantation, roasted and soaked at $(P<0.05)$ compared to control, while group E (Raw) showed significant decrease at $P<0.05$ compared to control (Fig. 5). This is attributed to the feeding of the experimental animals with the various forms of the processed Cajanus cajan the boiled, cooked, fermentation with decantation, fermentation without decantation, roasted and soaked.

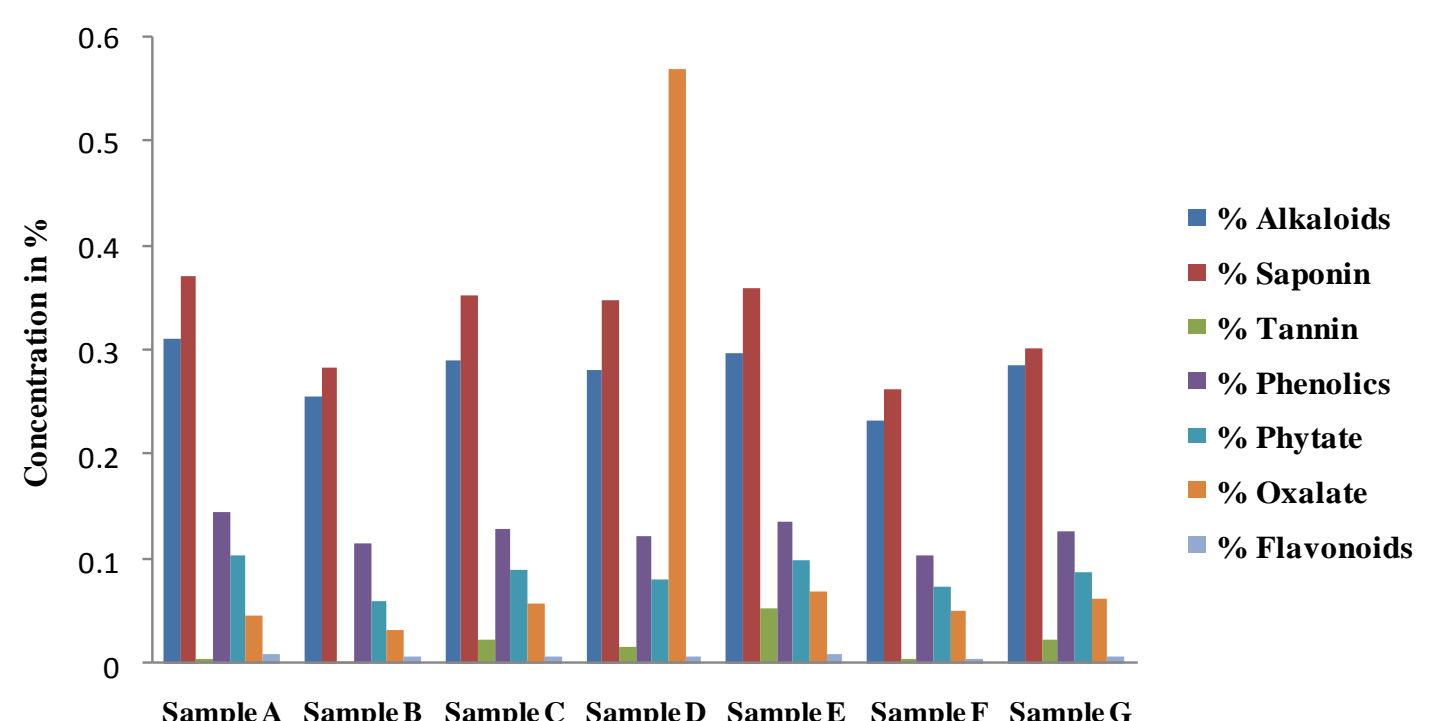

Fig. 1: The results of the quantitative phytochemical analysis of processed Cajanus cajan. 


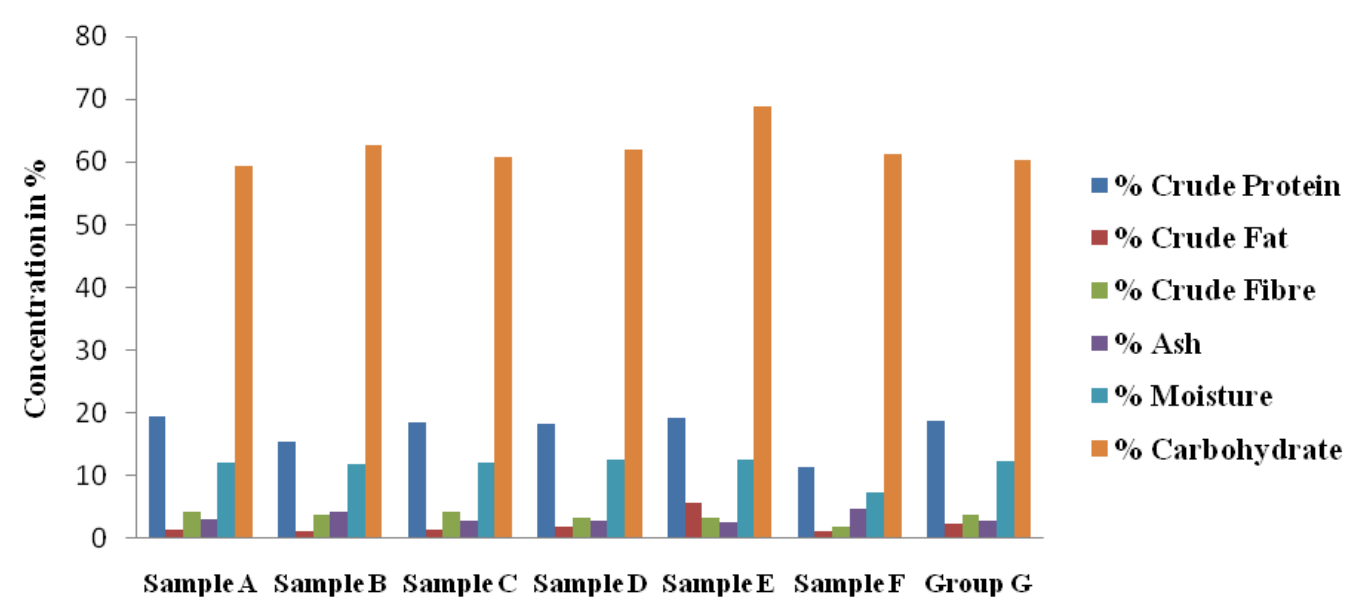

Fig. 2: The results of the proximate nutrients composition of processed Cajanus cajan.

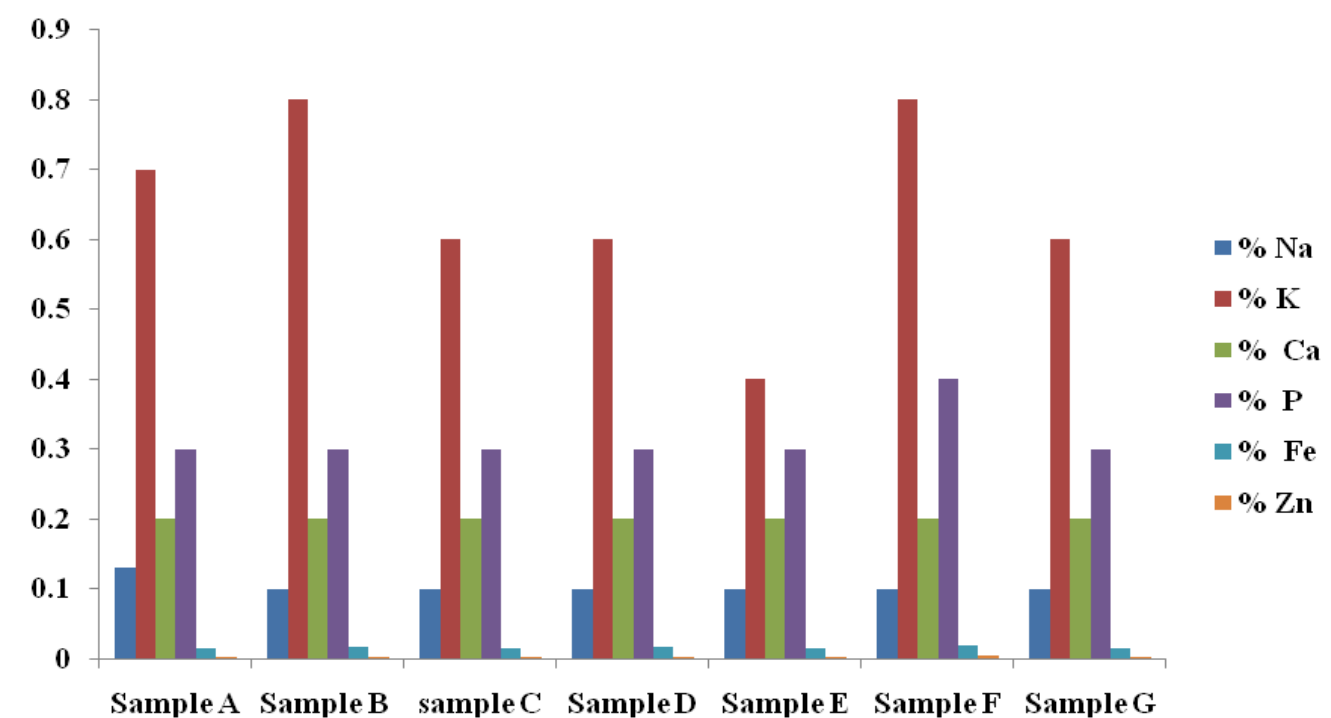

Fig. 3: The results of the mineral nutrients composition of processed Cajanus cajan.

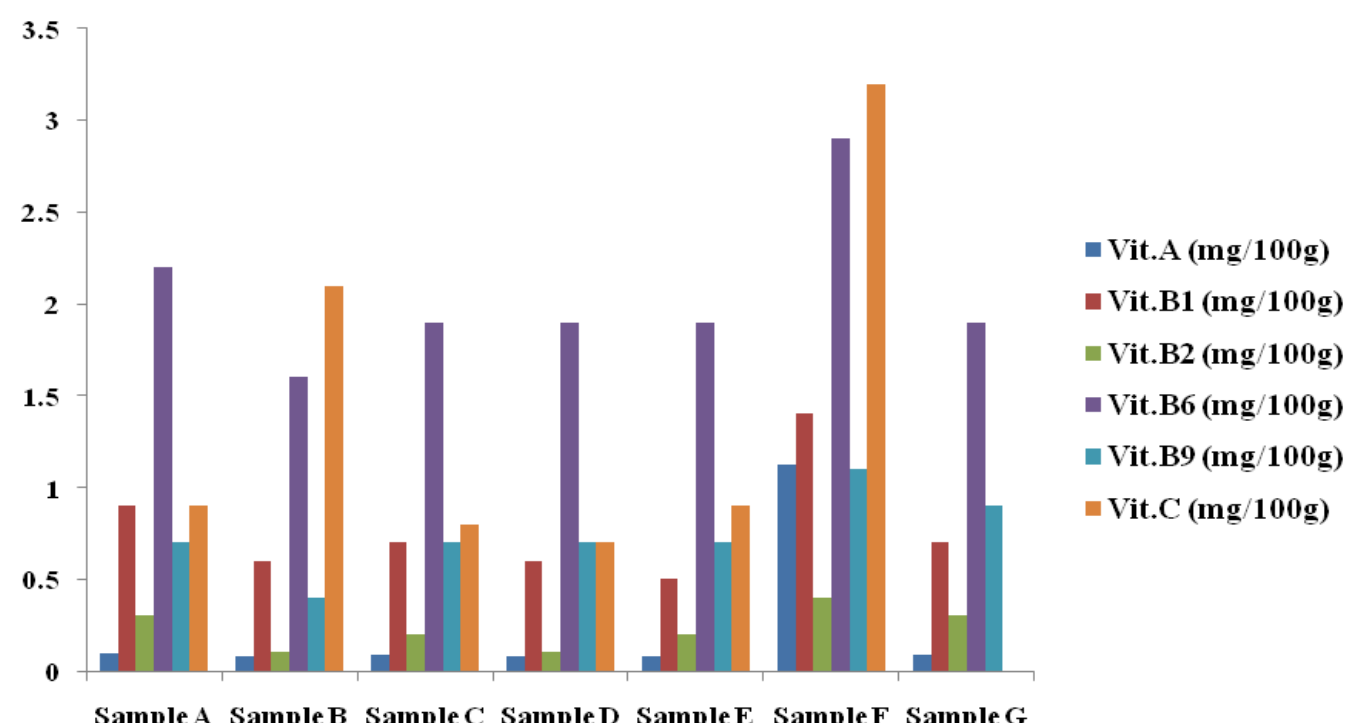

Fig. 4: The results of vitamins in processed Cajanus cajan. 


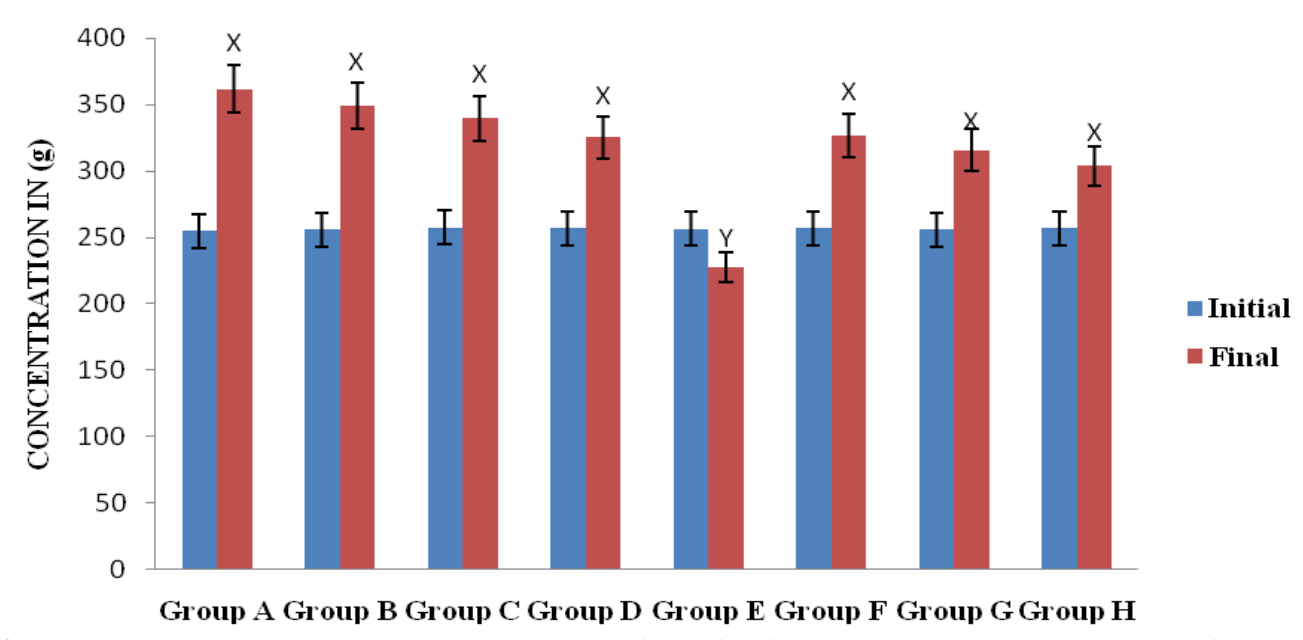

Fig. 5: Effect of processed Cajanus cajan on body weight indices. Values are expressed in Mean \pm SEM of 8 determinations; $\mathrm{X}=$ Indicates significant increase at $P<0.05$; Y=Indicates significant decrease at $P<0.05$.

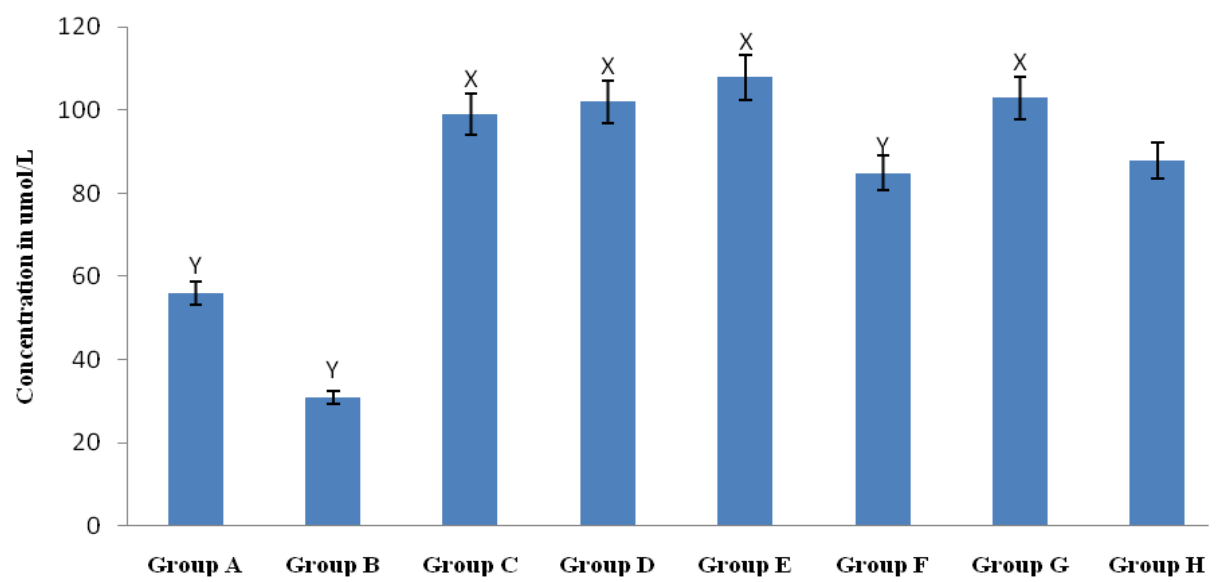

Fig. 6: Effect of processed Cajanus cajan on the creatinine level of the experimental rats. Values are expressed in Mean \pm SEM of 8 determinations. $\mathbf{X}=$ indicates significant increase at $P<0.05 ; \mathbf{Y}=$ indicates significant decrease at $P<0.05$.

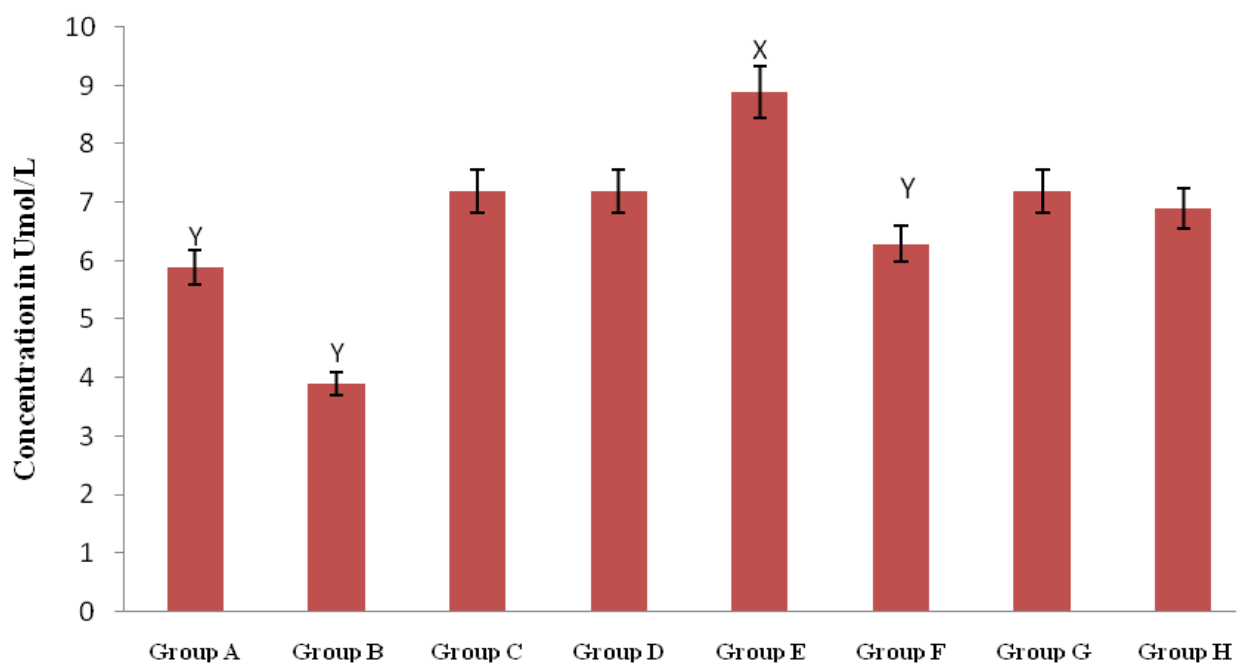

Fig. 7: Effect of processed Cajanus cajan on the bilirubin level of the experimental rats. Values are expressed in Mean \pm SEM of 8 determinations. $\mathbf{X}=$ indicates significant increase at $P<0.05 ; \mathbf{Y}=$ indicates significant decrease at $P<0.05$. 


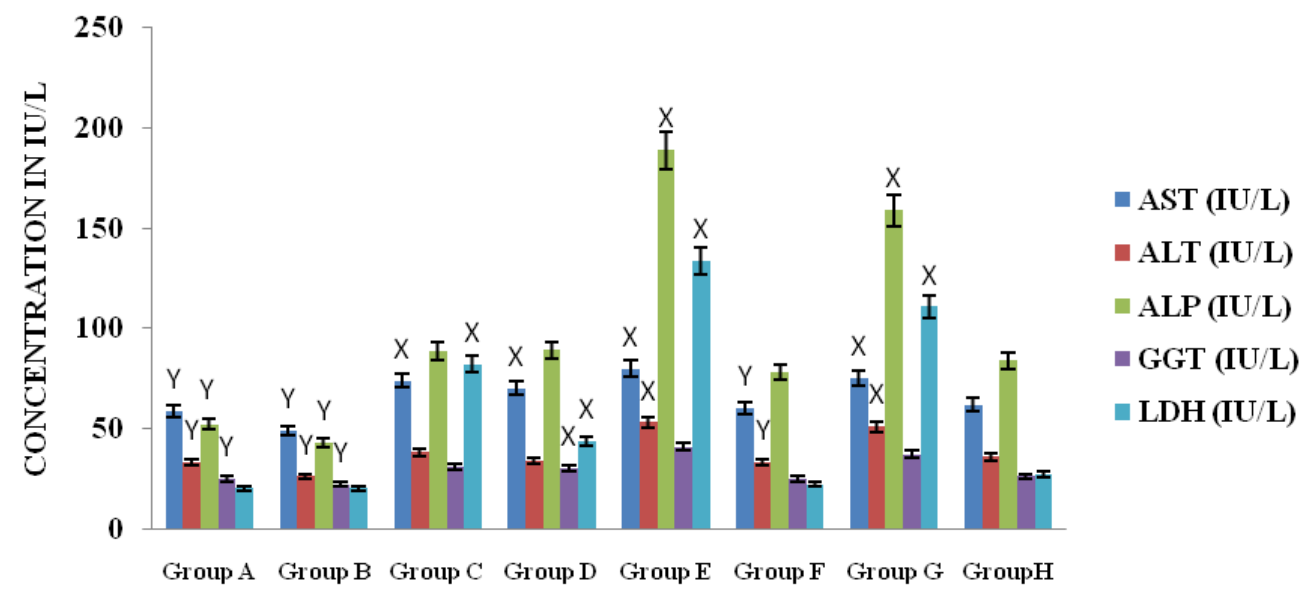

Fig. 8: Effect of processed Cajanus cajan on serum enzyme activities. Values are expressed in Mean \pm SEM of 8 determinations. $\mathbf{X}=$ indicates significant increase at $P<0.05 ; \mathbf{Y}=$ indicates significant decrease at $P<0.05$.

The renal activity of the experimental animals were also consider in this study by analysing the creatinine level, there was significant decrease in creatinine activity in group A, B and F (boiled, cooked and roasted) at $P<0.05$ compared to control, while the group C, D, E and G (Fermentation with decantation, fermentation without decantation, raw and soaked) showed significant increases at $P<0.05$ compared to control, it's due to inadequate release for nutrients needed for metabolic processes from this processing methods (Fig. 6).

The liver enzyme activity was also checked by considering the bilirubin level. The bilirubin level in group A and B (boiled and cooked) Showed significant decrease $P<0.05$ compared to control, while group $F$ (roasted) showed a decrease which was not significant compared to the control at $P<0.05$. While there was also an increase in groups $\mathrm{C}$, D and $\mathrm{G}$ (fermentation with decantation, fermentation without decantation and soaked) which was not significant at $P<0.05$ compared to control, but group E (raw) showed a significant increase at $P<0.05$ when compared to the control (Fig. 7). This is due to high level of anti-nutritional factors which are present in the raw Cajanus cajan such as the digestive enzymes inhibitor, which reduces protein digestibility. The hepatic serum enzymes are valuable tool in clinical diagnosis and it provides information on the effect and nature of pathological damage to tissues (Daisy and Saipriya,
2012). The serum enzymes considered in the research are the Aspartate Transaminase (AST), Alanine Transaminase (ALP), Gamma Glutamyl Transferase ( $\mathrm{\gamma}-\mathrm{GT})$ and Lactate Dehydrogenase (LDH). Serum AST and ALT enzymes are commonly used as indicators for hepatocellular damage. These enzymes are present in the liver in high concentrations and in conditions of hepatic intoxications leak into circulation, thus increasing level of the enzymes. This significant increase in the concentrations of these enzymes may be due to acute hepatocellular damage which may terminate into circulation. Comparing the AST and ALT level at the end of the experiment there was a significant decrease in groups A, B and F (boiled, cooked and roasted) when compared to the control at $P<0.05$, while groups C, D, G (fermentation with decantation, fermentation without decantation and soaked) showed an increase which was not significant at $P<0.05$ compared to control. However E (Raw) showed a significant increase at compared to the control at $P<0.05$. At $P<0.05$ the ALP level in group A and B (boiled and cooked) showed a significant decrease at $P<0.05$ compared to the control, while groups $\mathrm{C}, \mathrm{D}, \mathrm{F}$ (fermentation with decantation, fermentation without decantation and roasted) showed an increase which was not significant at $P<0.05$ compared to control. However group E and G (raw and soaked) showed a significant increase at $P<0.05$ compared to the control. The GGT activity in group A and B (boiled 
and soaked) shows a significant decrease at $P<0.05$ compared to the control, while groups C, D, F and $\mathrm{G}$ (fermentation with decantation, fermentation without decantation, roasted and soaked) showed an increase which was not significant at $P<0.05$ compared to control, but in group $E$ (Raw) there was a significant increase at $P<0.05$ compared to the control. The LDH activity in group A, B and F (boiled, cooked and roasted) showed significant decrease compared to the control at $P<0.05$, while groups $\mathrm{C}, \mathrm{D}, \mathrm{E}$ and $\mathrm{G}$ (fermentation with decantation, fermentation without decantation, raw and soaked) showed a significant increase at $P<0.05$ compared to control with group E (Raw) having the peak value (Fig. 8).

\section{Conclusion}

From the results obtained in this research, the effect of the processed Cajanus cajan on some serum enzymes level has shown that cooked Cajanus cajan is of more nutritional value due to reduction in the anti-nutritional factors in this processing method, as depicted in low serum enzymes level activities.

\section{Conflict of interest statement}

Authors declare that they have no conflict of interest.

\section{References}

Annor, G.A., Sakyi-Dawson, E., Ssaalia, F. K., 2010. Response surface methodology for studying the quality characteristics of cowpea (Vigna unguiculata)-based. J. Process Eng. 33(4), 606-625.

Bassey, O.A., Lowry O.H., Brock, M., 1946. A method for rapid determination of alkaline phosphatase with five cubic milliters of serum. J. Biol. Chem. 164, 321-329.

Casey, R., 1998. The seed composition of grain legumes. Proc. of the 3rd European Conference on Grain Legumes.Valladolid, Spain. pp.49-54.

Daisy, P., Saipriya, K., 2012. Biochemical analysis of Cassia fistula aqueous extract and phytochemically synthesized gold nanoparticles as hypoglycaemic treatment for diabetes mellitus. Int. J. Nanomed. 7, 1189-1202.

Enujiugha, V., 2010. The antioxidant and free radical-scavenging capacity of phenolics from African locust bean seeds (Parkia biglobosa). Adv. Food Sci. 32(2), 88-93.

Grant, G., Driessche, E., 1993. Legume lectins: Physicochemical and nutritional properties. Recent advances of research in anti-nutritional factors in legume seeds. E.A.A.P. Publication, No.70. pp.219-233.

Harbone, F. B., 1973 Phytochemical Methods: A Guide to Modern Technique of Plant Analysis. Chapman and Hall Ltd., London. 279p.

Jacobs, J.R., Gallagher, D.R., 2004. Whole grain intake and cardiovascular disease: A review. Curr. Atheroscler. Rep. 6, 415-423.

Kataria, H., 1995. Phytochemical investigation of medicinal plants Cnicus wallichii and Cnicus benedictus L. Asain J. Chem. 7, 227-228.

Khalil, I. A., Monan, F., 1990. Textbook of Chemistry, $2^{\text {nd }}$ Edn. Taj Kutab Kbana, Peshawar.

National Institute of Health, 2008. Guide for the care and use of laboratory animals 14, pp.89544.

Reitman, F.J., Frankel, E.T., 1957. Purification and characterization of aspartate aminotransferase from the halophile archaebacterium Haloferax mediterranei. Biochem. J. 278(1), 149-154.

Reyes-Moreno, C., Okamura-Esparza, J., ArmientaRodelo, E., Gomez-Garza, R., Milán-Carrillo, J., 2000. Hard-to-cook phenomenon in chickpeas (Cicer arietinum L): Effect of accelerated storage on quality. Plant Foods Human Nutr. 55(3), 229-241.

Reyes-Moreno, C., Paredes-Lopez, O., Gonzalez, E., 1993. Hard -to-cook phenomenon in common beans - A review. Crit. Rev. Food Sci. Nutr. 33(3), 227-286.

Salunke, D. U., Kadon, S. S., Charan, J. U., 1985. Postharvest Biotectnology of Food Legumes. CRC Press, Bocaraton, F.L.

Scheider, A.V., 2002. Over of the market and consumption of pulses in Europe. British $\mathrm{J}$. Nutr. 88, S234-S250. 
Sofowora, A.E., 1993. Medical Plants and Traditional Medicine in Africa. $2^{\text {nd }}$ Edn. Spectrum Books, Ibadan. 289p.

Solomon, S. G., Okomoda, V. T., Oda, S. M., 2017. Nutritional value of toasted pigeon pea, Cajanus cajan seed and its utilization in the diet of Clarias gariepinus (Burchell, 1822) fingerlings. Aquacult. Rep. 7, 34-39.
Trease, G.C., Evans, W.C., 1996. Phenols and Phenolics Glycosides in T and E Pharmacolosis. Braillere Tinall. London. pp.832-833.

Wright, A., Plummer, C., 1974. A fine-structure genetic and chemical study of the enzyme alkaline phosphatase of E. coli. I. Purification and characterization of alkaline phosphatase. Biochem. Biophys. Acta. 38(5), 470-483.

\section{How to cite this article:}

Ukpanukpong, R.U., Bassey, S. O., Adejoorin, M.A., Eko, C.I., Omang, W.A., Eyong, E.D., 2018. Effect of processed Cajanus cajan seed on some serum enzyme levels in albino Wistar rats. Int. J. Curr. Res. Biosci. Plant Biol. 5(8), 15-23. doi: https://doi.org/10.20546/ijcrbp.2018.508.003 